Review

\title{
Fungal Degradation of Wood: Emerging Data, New Insights and Changing Perceptions
}

\author{
Barry Goodell ${ }^{1}{ }^{\circledR}$, Jerrold E. Winandy ${ }^{2}$ and Jeffrey J. Morrell ${ }^{3, *}$ \\ 1 Microbiology Department, University of Massachusetts, Amherst, MA 01003, USA; bgoodell@umass.edu \\ 2 Bioproducts and Biosystems Engineering Department, University of Minnesota, St. Paul, MN 55108, USA; \\ jwinandy@umn.edu \\ 3 Centre for Timber Durability and Design Life, University of the Sunshine Coast, Brisbane 4102, Australia \\ * Correspondence: jmorrell@usc.edu.au
}

Received: 30 October 2020; Accepted: 8 December 2020; Published: 11 December 2020

\begin{abstract}
Wood durability researchers have long described fungal decay of timber using the starkly simple terms of white, brown and soft rot, along with the less destructive mold and stain fungi. These terms have taken on an almost iconic meaning but are only based upon the outward appearance of the damaged timber. Long-term deterioration studies, as well as the emerging genetic tools, are showing the fallacy of simplifying the decay process into such broad groups. This paper briefly reviews the fundamentals of fungal decay, staining and mold processes, then uses these fundamentals as the basis for a discussion of fungal attack of wood in light of current knowledge about these processes. Biotechnological applications of decay fungi are reviewed, and an overview is presented on how fungi surmount the protective barriers that coatings provide on surfaces. Advances in biochemical analyses have, in some cases, radically altered our perceptions of how wood is degraded, and even the relationships between fungal species, while other new findings have reinforced traditional perspectives. Suggestions for future research needs in the coatings field relative to enhanced fungal and environmental protection are presented.
\end{abstract}

Keywords: wood degradation; brown rot; white rot; soft rot; mechanisms of decay; coating performance; bioproducts; bio-coatings

\section{Introduction}

Wood is among the most durable cellulosic materials, but it can be degraded by a number of biotic and abiotic agents. These agents often act simultaneously making it difficult to completely separate causal agents. This review will concentrate on the role of fungi in degradation but will also discuss other agents as they relate to the overall process. Our discussion will focus on those fungi capable of degrading the primary cell wall polymers of cellulose, hemicellulose and lignin, but will also touch on the many mold and stain fungi that not only cause aesthetic concerns and disfigure coatings but can digest the stored compounds in the parenchyma cells and the pit membranes while promoting more limited damage to the structural elements of wood.

Wood poses a major challenge to organisms seeking to extract the energy from its polymeric structure. While the stored compounds in parenchyma cells are digestible by many organisms, accessing the more complex polymers is a key challenge. The chemistry and arrangement of the cellulose and lignin polymers in the wood cell wall sharply reduces the number of agents capable of causing damage. Many fungi are cellulolytic but are unable to unlock the chemistry of the lignin polymer that both enrobes and is interspersed with the cellulosic components of the lignocellulosic matrix. Only those fungi that have developed strategies to surmount the recalcitrance of lignin are able to fully extract the embodied energy of the lignocellulose cell wall. 


\section{Wood as a Polymeric Material}

Cellulose represents $40-44 \%$ of most wood and endows wood with many of its unique material properties [1]. At the nanoscale, cellulose is arranged in discrete units known as elementary fibrils, with the inner core of those fibrils being a tightly packed crystalline material and the outer layers being more loosely packed amorphous cellulose. The crystalline nature of the inner core of the elementary cellulose fibrils gives wood its exceptional tensile strength - comparable to steel and aramid (Kevlar) at the nanoscale [2]. Crystallinity also renders the inner portion of the cellulose elementary fibril more resistant to degradation than the other more amorphous carbohydrate polymers also present in the wood cell wall.

Lignin represents 18 to $35 \%$ of the wood cell wall and is a heteropolymer consisting of repeating units of phenyl propane with a diverse array of bonds between three variations of the monomer form. This diversity in bonding pattern makes lignin extremely resistant to degradation and few microorganisms other than select wood degrading fungi have been able to unravel this system. Furthermore, the higher levels of lignin in wood compared to other plant materials, and manner in which lignin is intimately integrated with the holocellulose components, are major reasons for wood's resistance to degradation.

Hemicellulose is a branching heteropolymer of pentose and hexose sugar monomers representing $15-32 \%$ of the wood cell wall. Hemicellulose is a more amorphous polymer compared to cellulose, and it is considered to be the link between cellulose and lignin that allows the three polymers to behave as an integrated matrix. Hemicellulose is also more susceptible to degradation and the many forms of the hemicellulose polymer can be degraded by excessive heat such as that occurring in thermal modification processes used in industrial wood protection [3,4], or by relatively dilute acids, as was observed with significant mechanical property losses following treatment by some early-industrial acidic fire-retardant and preservative formulations [5]. These forms of degradation are discussed more completely in the section on Abiotic Degradation below. Important relative to this chapter are several types of fungi that attack hemicellulose in early stages of decay leading to mechanical property loss [6]. Although hemicellulose is an integral part of the wood structure, it is often viewed as the weak link in the armor of wood as a material, since its degradation profoundly affects the ability of lignocellulose to behave as a rigid structural system. Hemicellulose is often the first major component of wood to be attacked and deconstructed by fungi $[7,8]$.

In addition to the cell wall polymers, other components including proteins, fatty acids, pectin, starch and other polysaccharides and sugars are also present at levels ranging from 2 to $15 \%$ (Average $\sim 6 \%$ ) of the wood mass [1]. While these materials can have dramatic effects on resistance to microbial attack, this review will concentrate on the roles of the three primary cell wall polymers in relation to fungal attack.

\section{The Importance of the Wood-Water Relationship}

Water is an important constituent of wood materials and biomass in the natural environment and can affect wood properties both directly and indirectly. The uptake of water is an integral factor associated with wood's ability to be attacked by fungi and to decay, but moisture also impacts wood by moving into the cellular structure to associate with the cellulose, causing dimensional changes. Even though water is held in wood primarily by hydrogen bonding at the molecular level, the collective force of the hydrogen bonds formed is sufficient to swell the wood to the extent that, at a practical level, is capable of splitting rocks, tearing thin metal plates or forcing structural walls apart. Shrinkage and swelling of wood with changes of humidity in the environment creates substantial challenges for coatings. Polymeric coatings typically are unable to prevent moisture vapor from diffusing in and out of wood as humidity changes. This results in repeated swelling and shrinkage of wood, particularly in exterior environments. Few polymeric coatings can withstand the recurring cycles of expansion and contraction that wood surfaces undergo with significant humidity changes. 
The stress on wood coatings due to moisture changes, combined with other factors such as mechanical action and abrasion, creates an environment where coatings are subject to rupture at the microscopic level. Wood surfaces are subjected to a continual dusting of fungal propagules that, once moisture levels and environmental conditions are correct, can germinate and exploit the micro-cracks that can develop in coatings. This will be addressed in the section on future research needs for bio-based coatings.

\section{Abiotic Degradation}

Non-living agents can cause different types of wood degradation that are often confused with fungal degradation. For this reason, it is important to review some of the most important abiotic (non-biological) degradation agents which are often confused with fungal attack of wood.

Wood weathering is the most common type of non-biological degradation occurring in exterior-use wood [9]. The low energy levels in sunlight can be quite disruptive to the polymeric components of wood at the molecular level. During UV (sunlight) exposure, the primary energetic components which can attack lignocellulose are reactive oxygen species (ROS or oxygen radicals) that randomly attack the cell wall polymers, especially lignin. This energy transforms lignin into a variety of radical forms that transfer the energy to hemicellulose and cellulose which are then readily depolymerized $[10,11]$. This process begins almost immediately after timber is exposed to sunlight, but the effect on the timber is shallow until the outer layers of UV-degraded wood are sloughed off. Weathering related to UV exposure is typically slow but can have substantial effects on adhesion of coatings as well as declines in appearance leading to premature replacement. For example, a preweathering exterior exposure of Western redcedar siding in direct sunlight for 1, 2, 4, 8 or 16 weeks prior to being painted reduced paint adhesion by up to $50 \%$ [12,13]. Increased preweathered was associated with shorter paint service life: paint on panels preweathered for 16 weeks began to flake and peel after 4 to 5 years; preweathering for $8,4,2$ or 1 weeks resulted in paint failures after 7 to 8 years, 9 to 10 years, 10 to 11 years or 13 years, respectively. Coatings on non-preweathered controls were still in almost perfect condition after 17 years of exposure.

Another common abiotic source of wood degradation that can be confused with fungal attack is heat- or thermal degradation. Wood has a well-known propensity to burn, but it also experiences more subtle changes upon extended exposure to temperatures between $65^{\circ} \mathrm{C}$ and the ignition point $[5,14]$. Heating affects each polymer differently, with hemicelluloses being the most susceptible, followed by cellulose and finally, lignin [15]. Thermal-related modification can have negative effects on wood, particular if the wood has been modified with other treatments such as some types of fire-retardant treatment. In the 1980s, most of the fire retardants used in North America were acidic. During that period, issues gradually emerged where fire-retardant treated wood in structures began experiencing extensive degradation $[5,16]$. Subsequent investigations showed that the acidic formulations tended to react with, and degrade, wood maintained at temperatures typically found in attics and enclosed roof spaces during the summer. Further study revealed that hemicelluloses were the first polymers affected, again illustrating the critical role played by these polymers in lignocellulose performance [14]. Disruption of the biological degradation process by thermally modifying hemicellulose has been studied since the 1930s [17]. This research was initially directed at modifying colors to render lighter, less valuable woods darker, but it was also shown to affect wood/moisture relationships. The process was never fully exploited, but was revisited in the 1980s as European researchers sought non-biocidal methods for improving timber durability [4]. Extensive subsequent research has shown that thermal modification alters the hemicelluloses, thereby reducing moisture uptake which in turn reduces, but does not completely eliminate, the risk of decay.

\section{Biotic Deterioration-Wood Decay and Requirements for Fungal Attack}

Wood decay is largely caused by fungi that fall into categories depending on the appearance of the degraded wood which is, in turn, related to polymeric materials that are degraded. Brown rot decay is 
an informal name for the most common type of decay occurring in timber products. Fungi that cause brown rot depolymerize cellulose and hemicellulose (holocellulose) for digestion, while lignin is also depolymerized and modified before being rapidly repolymerized. The general categories of white rot fungi and soft rot fungi are the other major types of decay, and these are covered later in this review, as these fungal decays can be quite important in certain environments. Fungi are Eukaryotic organisms that are in the same Domain in the Tree of Life as plants and animals [18]. Species within other Domains in the tree of life comprising the Bacteria and Archaea can also live in wood. Some species of Bacteria have been shown to cause limited wood deterioration over long periods of time (several centuries), resulting in mechanical property loss in wood. Because of their minor importance in deterioration of structures, these microorganisms will not be considered further in this chapter, although we recognize that they are almost always present and have been suggested to play supporting roles in the degradation process including pre-conditioning of wood, and extractives detoxification. Bacteria are also active in long-term degradation of submerged wooden foundation piling, which typically occurs over many centuries [19]. Insects and some types of marine boring animals also can cause significant biodeterioration of wood under some circumstances, but deterioration by these animals is reviewed elsewhere [20].

For all fungi, spores (microscopic seeds) or other small fragments of the fungi must be produced and be transported either in the air, water or on other organisms (such as insects) to other pieces of wood where a new fungal colonization can initiate. Several requirements must be met for colonization to occur. In addition to the wood substrate itself, these include:

\subsection{Water and Air}

Typically, wood must be at or near the point where the wood cell wall is saturated with "bound" water, known as the fiber saturation point (FSP) for the fungal spores or fragments to germinate and initiate new fungal colonies. There is considerable debate about the minimum moisture level required for fungi to colonize and decay wood exposed out of soil contact [21]; however, because the filamentous strands of fungi (hyphae-see Fungal Physiology/Anatomy below) are required to be surrounded by a watery extracellular polysaccharide matrix (ECM) when wood is being attacked, some level of free moisture in the wood cell lumen is required to support fungal growth. In most cases, fungal decay can begin at approximately 30\% moisture content (oven dry basis), reaching an optimum between 40 and $80 \%$, then declining with increasing moisture levels above $100 \%$ as cell lumens begin filling with water and oxygen becomes limiting. Water is often the most important limiting factor in decay, and some paradigm-shifting current literature [22] focuses on the critical moisture content that allows fungal metabolites responsible for depolymerization of the wood polymers to diffuse within the wood cell wall. However, fungi require liquid water to initiate the secretion of metabolites required for decay, even in the absence of wood or other suitable substrates. Because the biosynthesis of these metabolites is a prerequisite for their diffusion within the cell wall, it is important for wood to first attain a moisture content where fungi can synthesize metabolites as well as one that supports robust ECM production surrounding and attaching the fungal cells to the wood cell wall to allow compounds to diffuse between fungus and the wood cell wall. In this regard, appropriate moisture conditions for fungal activity are required even before diffusional aspects of metabolites within the wood can be considered, and inhibition of fungal ECM production represents a fruitful area for future research in controlling fungal growth.

Wood in contact with the ground is frequently above the FSP and, in addition to having a fully saturated cell wall, contains liquid water in the lumens of the fibers. For fungal growth to occur in wood, the moisture content of wood must also not be too high to preclude adequate oxygen levels. Although fungi do not require as much oxygen as humans, they are aerobic organisms and wood decay fungi typically will not grow on wood that is completely saturated or submerged. Oxygen is rarely limiting for fungal attack, although complete saturation of logs by "ponding" (submersion in natural or artificial bodies of water) has been used to limit decay for periods of several months prior 
to processing in mills. In some cases, logs that sank during freshwater storage have been retrieved decades and sometimes even centuries later and processed with little deterioration noted. Many of these logs remain on the bottom of fresh water bodies and are in pristine condition because of the lack of oxygen, and also because relatively cold temperatures limited anaerobic bacterial deterioration.

\subsection{Temperature}

Temperature is critical for most physiologic reactions. Fungi may continue to grow as temperatures decline to levels near freezing [23], but reaction rates involved in both fungal metabolism and in the chemistry/biochemistry of wood depolymerization decline, and the decay process ultimately stops at freezing temperatures. Metabolic reactions increase with increasing temperature with most fungi having growth optima between 24 and $32{ }^{\circ} \mathrm{C}$ [20]. This is well within the temperature range inside most inhabited structures but specialized fungi can grow well outside this range. As a result, temperature is generally not a limiting factor in decay. For most decay fungi, fungal metabolism becomes more constrained as temperatures exceed $39-40^{\circ} \mathrm{C}$; however, some thermophilic fungi survive and have been observed to be active at temperatures exceeding $50^{\circ} \mathrm{C}$ in specialized environments such as pulp chip piles [24,25]. Exposure to temperatures about $56{ }^{\circ} \mathrm{C}$ results in permanent denaturing of proteins and DNA, effectively killing most non-thermophilic organisms.

\subsection{Other Essential Components for Fungal Growth and Decay Potential}

As noted above, a primary requirement for decay is a nutrient source which is typically the timber itself. This wood or surrounding supporting materials/soils must also contain various micronutrients and microelements, including nitrogen, that are essential to fungal growth and the decay process. There are vast volumes written about the relationships between decay and wood properties, e.g., [26]. Relatively few fungi have evolved the ability to degrade and utilize the three primary cell wall polymers, and the mechanisms by which they accomplish this task will be the subject of the remainder of this paper.

\section{The Decay Environment}

Many microorganisms are ubiquitous and will colonize almost any substrate meeting the basic requirements for growth of oxygen, food, moisture \& temperature. However, the nature of the wood substrate affects the types of wood degrading fungi that attack it, the colonization patterns, and the rates at which wood is utilized. For this discussion, we will ignore aquatic environments and concentrate on the terrestrial decay process. Decay can be categorized as either in ground or above ground, recognizing that these are arbitrary terms that overlap at their margins. In-ground or ground-contact decay is typically more rapid, reflecting the presence of adequate moisture along with an abundance of organisms with differing wood-attacking or wood-inhabiting capacities that are always present and in competition with each other. The above-ground environment is more challenging with fewer organisms present, and a greater potential for drying that can slow the decay process. There is also more limited potential for the transfer of moisture and exogenous nutrient resources into the wood and into the fungal thallus. These differences result in dramatic differences in the rates of degradation as well as substantial changes in the organisms involved.

\section{Basics of Fungal Anatomy/Physiology and Evolution}

\subsection{Biology and Evolution}

Within the Eukarya, the Kingdom of Fungi are classified into Subkingdoms and further into Orders/Divisions. The subkingdom of Dikarya, which are fungi that largely produce filamentous cells known as hyphae, are of particular interest with regard to coatings [27], and are described in more detail below. Two Orders are encompassed by Dikarya, the Basidiomycota and the Ascomycota, and both can play significant roles in wood and/or coating degradation. Ongoing research suggests 
that both Basidiomycota and Ascomycota evolved from earlier progenitor fungi between 400 and 500 million years ago [28-31], with species of white rot fungi that had the ability to decay lignocellulose evolving only perhaps 280 million years ago within a Class of fungi known as the Agaricomycetes [31]. Present day Agaricomycetes include many well-known mushroom-producing species, but many of the Agaricomycetes are rather nondescript in their macroscopic features, yet they have the ability to aggressively attack wood and disrupt any overlying coating materials.

It is interesting to note that plants initially evolved the ability to produce the cellulosic components of their cell walls long before they evolved the ability to produce lignin, which only later started to appear as a cell wall component in some types of woody plants [32]. Lignin "stiffened" the cellulose into a rigid polymer-matrix composite, allowing the precursors of modern-day trees to grow much taller than the grasses and sedges which existed prior to the Devonian period. The first lignin-producing plants evolved about 420 million years ago [33], long before fungi evolved enzymes and non-enzymatic systems with the capacity to depolymerize and further degrade lignin. Precursors to white- and brown rot fungi evolved lignin-degrading enzymes only about 295 million years ago [32], meaning that woody biomass was unable to be efficiently degraded by fungi for approximately 125 million years, and it has been proposed that inability to decay wood over this period of time led to the formation of coal seams in many areas of the world. However, some geology experts [33] examining fossilized woody tissue from the Carboniferous period dispute this premise and report that fungi were present in the fossilized wood cells showing "evidence of decay that is pervasive", suggesting that the fungi of that period were still somehow capable of decaying the woody tissues. However, the authors do not show convincing evidence of fungal attack of wood cell walls, and the images of fossilized fungal hyphae they present for interpretation are larger in diameter, and more consistent with non-decay Ascomycota species rather than Basidiomycota decay fungi. This suggests that there is still much more to be learned about the how wood decay fungi arose on earth, and their impacts, including the impact they have in decaying current day wood products and disrupting the coatings on those products.

\subsection{Growth and Infection of Wood}

Wood decay fungi primarily initiate as fungal spores or mycelial fragments. If conditions are favorable, spores germinate to produce fine hair-like structures known as fungal hyphae, which are elongated cells of the fungus which grow end-to-end. Hyphal fragments landing on wood can also in many cases initiate growth leading to broader colonization of the wood. Single-celled fungal growth is not common in wood degrading fungi except during spore formation. As the fungal hyphae grow along the surface of materials, some species can form a mat consisting of multiple layers of interwoven hyphae known as mycelium or a mycelial mat. The tips of the fungal hyphae initially seek out relatively simple pathways through the microstructure of wood, exploiting interconnecting cell wall pits (interconnecting channels between wood cells) to extend from one fiber to the next, and ramifying through the wood in this manner. During this initial growth phase, all wood-inhabiting fungi seek out stored products in the parenchyma as a ready nutrient source for energy for the fungus, and also to build up fungal biomass within or on the surface of the wood structure. This initial stage of growth of decay and some stain fungi results in activation of biochemical "machinery" within the hyphae resulting in secretion of a diverse suite of extracellular metabolites and enzymes that can depolymerize and digest select polymeric components of wood. One of the most common ways to measure wood degradation in laboratory studies is to monitor mass loss as decay progresses and wood cell wall components are converted to $\mathrm{CO}_{2}$ by the fungus. Although mass loss is not always an adequate indicator of structural strength loss, it is a straight-forward means for assessing some types of fungal degradation. Fungi have diverse suites of metabolites and enzymes that effect deterioration, and the discussion below provides information on how these fungi can be differentiated and how they may degrade wood in different ways.

Decay types: brown rot white rot, soft rot and their effects on wood chemistry: The fungi that degrade the cell wall polymers have long been segregated on the basis of the appearance of the 
damaged wood into brown, white and soft rot fungi. These separations are arbitrary and we now recognize that the decay types are more of a continuum [34], but the categories are helpful in generally classifying these fungal degradative agents, and for discussion.

\subsection{Brown Rot Fungi}

After the initial colonization stages, brown rot fungi primarily utilize the carbohydrate polymers of the wood cell wall, although they affect all three polymers. Brown rot fungi are considered to be more commercially important from a structural damage perspective because they tend to attack softwoods which represent the bulk of timber used in North American and European construction. However, they can also attack hardwoods and will readily do so in some environments [35]. The resulting decayed wood has a brownish, fractured appearance (Figure 1). The most important aspect of brown rot decay is the tendency for these fungi to produce degradation far in advance of the point of hyphal growth at the cellular level, and to depolymerize the carbohydrates much faster than they can be utilized. This results in very dramatic changes in many timber properties even when the macroscopic visual appearance of the wood is little changed. The result is very rapid losses in properties such as tension or bending at very low mass losses $[26,36]$.

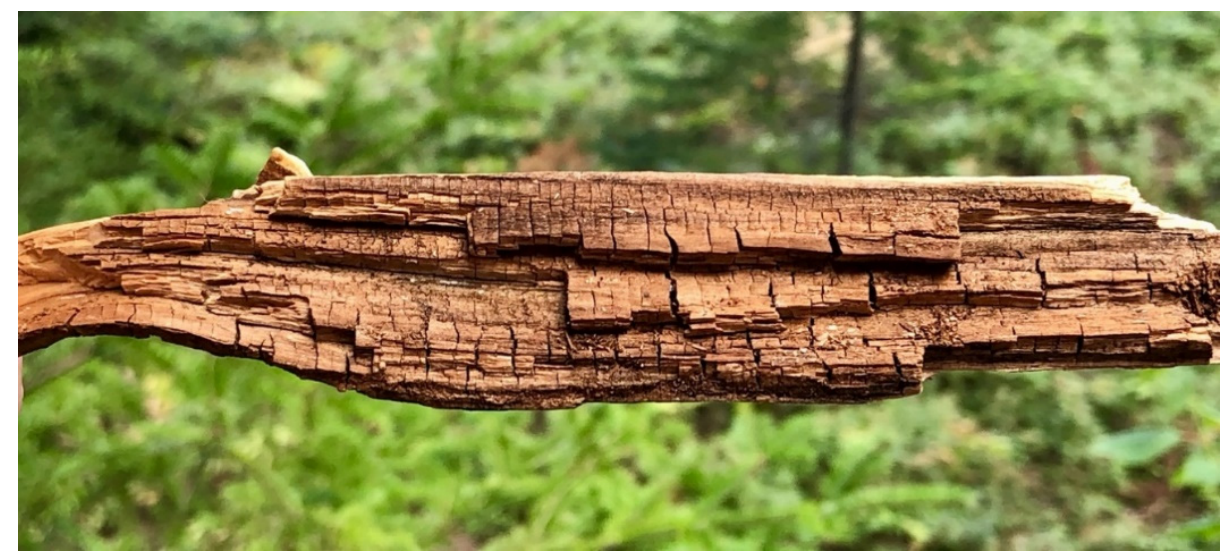

Figure 1. Classic advanced brown rot fungal decay in a softwood. Note the checks (cracks) which cut across the grain of the wood giving the wood a cubical appearance. In early stages of brown rot decay, the wood can appear unchanged from undecayed wood, yet significant mechanical property loss may be sustained even in early brown rot decay stages.

Brown rot fungi have a more limited suite of enzymes involved in the depolymerization and deconstruction of cellulose compared to white rot fungi, and they possess no peroxidase enzymes for lignin depolymerization. However, brown rot fungi rapidly attack and degrade cellulose while also using a non-enzymatic mechanism to depolymerize lignin to allow access to the cellulosic components. The lignin then rapidly repolymerizes, leaving a modified lignin that long led researchers to conclude that brown rot fungi had little effect on this polymer. This unique oxygen radical-based chemistry known as the "chelator-mediated Fenton" (CMF) system functions in advance of enzymatic action to deconstruct wood polymers [37]. CMF chemistry is more complex than conventional Fenton chemistry and allows brown rot fungi to generate powerful hydroxyl radicals within the wood cell wall rather than next to the fungal hyphae (which would kill the fungus). CMF chemistry causes lignin to depolymerize and then repolymerize as small, discrete irregular masses, separate from the cellulose [38,39], thereby opening the wood cell wall to further deconstruction. This type of chemistry is being studied as an efficient mechanism for lignin processing in future biorefineries. This later aspect may be of importance for modifying lignin for use in polymeric coatings and is reviewed further in the section on biotechnological applications. 


\subsection{White Rot Fungi}

White rot fungi can depolymerize all three cell wall polymers using enzymes secreted by the hyphae, often leaving a whitened mass of fibers at the advanced stages of decay (Figure 2). White rot fungi metabolize all three cell wall polymers and can cause weight losses approaching $97 \%$ of the original wood. Most white rot fungi are known as "simultaneous" white rots and tend to digest and utilize the wood polymeric components as they are depolymerized. However, some "selective" white rot fungi can preferentially digest the hemicellulose and lignin components leaving much of the crystalline cellulose relatively undegraded. In either type of white rot, structural losses occur more slowly than in brown rots, and cell wall depolymerization is more directly linked to enzymatic erosion of the cell wall layers and also to the metabolic processes of the fungus. This coupling of degradation with utilization results in declines in properties such as tension or bending that parallel mass losses caused by decay. White rot fungi tend to attack hardwoods, but can also attack softwoods [35]. Carbohydrate active enzymes (CAZymes) and lignin degrading enzymes from white rot fungi have been previously explored for use in pulp and paper processing, and other industrial processes to free lignin from wood fiber with reduced use of harsher chemicals.

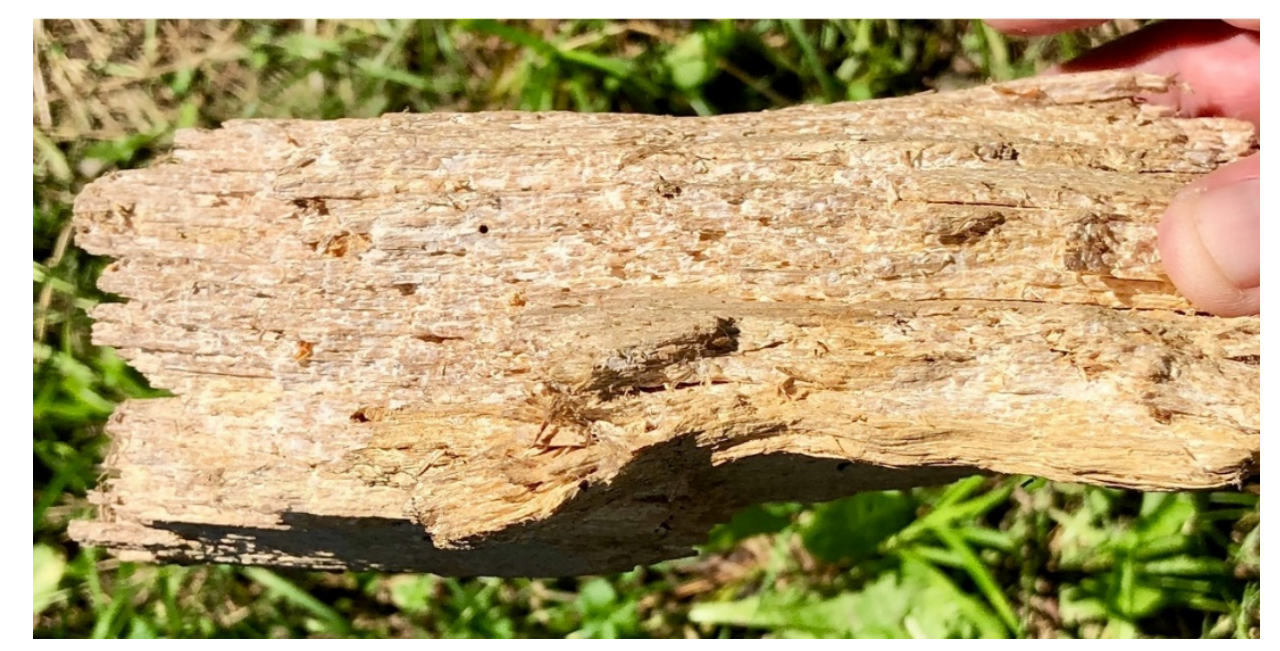

Figure 2. Advanced stage of white rot simultaneous decay. The wood in this advanced state of decay can be quite spongy and lightweight when dried. However, when decay is active, the wood will be moist and stands of wood can often be peeled from the surface along the grain. The flecks of white in the image are mycelial mats of the fungus.

Enzymes of specific importance in lignin degradation by white rot fungi are primarily oxidative and include: laccase, lignin peroxidase, manganese peroxidase, versatile peroxidase and the dye-decolorizing peroxidases [39]. Many of these enzymes are unique to white rot fungi with only a relatively few dye-decolorizing peroxidases, for example, found in select lignin-degrading bacteria. Relative to CAZymes, white rot fungi have a much more complete suite of glycoside hydrolases and also lytic polysaccharide monooxygenase enzymes that can attack cellulose both from the ends of the long-chain polymer (exo-glucanases) as well as centrally along the polymer chain (endo-glucanases). This dual action, combined with a suite of enzymes that can act on oligosaccharide depolymerization products, allows white rots to deconstruct a variety of holocellulose polymers.

\subsection{Further Evolution of Brown rot Fungi from the Precursors of White Rot Species}

Brown rot fungi evolved relatively recently from white rot fungi starting about 280 million years ago in the Permian period [31]. Only 20 years ago, brown rot fungi were looked upon by most mycologists as less evolutionarily advanced because many of the CAZymes and all of the lignin-degrading peroxidase enzymes in the precursor white rot fungi were lost as the brown rot fungi evolved. The brown rot fungi 
now dominate wood decay in the coniferous forests of the northern hemisphere, and there are chemical wood-processing efficiencies that can be learned from studying their evolutionary divergence from the white rots. Enzymes from both white and brown rot fungi are too large to penetrate the intact wood cell wall, and some form of chemical "pretreatment" is typically needed before enzymes can function efficiently in deconstructing the wood cell wall. The evolution of the bio-catalytic CMF mechanism by brown rot fungi is generally considered a key step that allowed these fungi to more efficiently deconstruct wood without the production of nutritionally costly enzymes. The CMF mechanism has considerable promise for use in the bioprocessing of lignocellulosic materials [39]. Enzymatic systems in industrial processes are widely used for a variety of applications to reduce energy inputs required for catalysis but enzymes can be fragile and often require highly specific reaction conditions including specific temperatures and buffering systems. Mimicking bio-catalytic processes without the use of enzymes may be a fruitful pathway for industrial processing for bio-based coatings.

\subsection{Soft Rot Fungi}

Although soft rot damage of wood was first observed in the 1860s, soft rot fungi were not classified as a decay type until the 1950s [40]. Most soft rot fungi are Ascomycota species. There are two types of soft rot attack. Type 1 soft rot involves formation of diamond-shaped cavities aligned with the cellulose microfibril angle within the S-2 cell wall layer, while Type 2 is a more generalized erosion of the S-2 cell wall layer from the lumen outward [20]. Type 2 attack is more prevalent, but some species can produce both types of damage depending on the timber as well as environmental conditions [41]. Soft rot fungi are often found in more extreme, and wetter conditions that are less suitable for traditional white and brown rot fungi [39]. Their damage tends to be confined to the external few mm of wood that is exposed to the environment, possibly because oxygen levels are too low in interior wood below ground to support more aggressive Basidiomycota fungal species. However, particularly in Scandinavian reports, soft rot has been observed to extend more deeply in some products such as utility poles. Soft rot damage presents an interesting mixture of white and brown rot characteristics in that these fungi utilize both cellulose and hemicellulose, but they can clearly degrade lignin as evidenced by the cavities and erosion they cause. Several soft rot fungi are known to produce laccase which is also involved in lignin degradation by white rot fungi [39].

Soft rot fungi tend to have very large, but localized effects on wood properties and these effects are magnified because the damage tends to be on the exterior of the timber where flexural properties for products such as utility poles become more important. In other products, such as boards that will be used for paneling, soft rot fungi can impart an appearance that some people consider as desirable for rustic interiors, and because only the surface wood is degraded, these fungi can sometimes be considered as enhancing the properties of certain wood products.

\section{Specific Fungal Chemistries that Impact Polymeric Coatings and How These Can Be Harnessed for Biotechnological Applications}

The characteristic ability of all three decay types to attack the three primary wood polymers highlights the effect of wood cell wall chemistry on convergence of fungal strategies for accessing these resources, but differences in processes creates potential opportunities for the using these fungi in industrial biomodification processes. The most heavily researched applications have been delignification for pulping and biodetoxification of xenobiotic pollutants, but fungi could also be used to modify various polymeric materials including those used for wood coatings.

\subsection{White Rot Fungi}

White rot fungi have been used in biotechnological and bio-processing applications for more than 40 years [42-44]. White rot fungi have been studied since the 1970s to free cellulose from lignin and release individual fibers in bio-based pulping systems. Wood composites have also developed by using isolated lignin from pulp liquors, or lignin residues that migrate to the surface of wood fibers during 
pulping. In both cases the lignin is modified to produce a "sticky" lignin radical by white rot fungal enzyme systems including peroxidase and laccase-mediator systems [45,46]. Similarly, laccases have also been used to create bioactive polymer coatings using soft plasma jet processing [47]. The ability of white rot fungi to depolymerize lignin has also been extensively explored for bioremediation of structurally similar pollutants and xenobiotics but the applications have been limited because many sites are anaerobic [48,49]

The emerging bio-economy, the development of biorefineries and the production of cellulose-derived sugars for fermentation and direct conversion to biofuels and platform chemicals have all created renewed interest in application of white rot fungi [50,51]. A number of white rot species, including Pycnoporus cinnarbarinus, Phlebia subserialis, Dichomitus squalens and Ceriporiopsis subvermispora, have been assessed for use in the bioprocessing of wood to make bio-based products and energy, but there is considerable opportunity to expand the suite of organisms to take advantage of the range of enzymatic capabilities [52]. Early researchers who explored bio-based deconstruction of wood for pulp fiber focused primarily on complete lignin removal, but subsequent studies showed that some white rot fungi had more subtle effects that resulted in reduced energy requirements in mechanical pulp production while improving other paper properties. Bio-bleaching of pulp using Phanerochaete crassa, P. chrysosporium, and Pleurotus pulmonarius previously has been studied for replacement of chlorine in conventional pulp bleaching processes $[53,54]$, but bio-bleaching using these organisms has not been commercialized, illustrating the difficulty in scaling up laboratory results.

The need for oxygen and the filamentous nature of white rot fungi has largely limited most applications, but several of the CAZymes as well as the lignin degrading enzymes have been cloned into yeast and bacterial vectors for use in biorefinery applications. Many peroxidases have broad capabilities to oxidize phenolic substrates and could be used to activate phenolic-based coatings. Additional research in this area using enzyme cocktails, including the use of relatively newly discovered lytic polysaccharide monooxygenase (LPMO) enzymes, is needed to enhance platform chemical yield from biomass [55].

The desire for more sustainable processes for producing polymers and coatings using fungal peroxidases should encourage a re-evaluation of previous biomass conversion research, which was often discarded because the economics could not compete with less sustainable processes [56]. Fungal derived peroxidases could be used to provide platform chemicals for further synthesis. While lignin remains a puzzling and complex polymer that has largely defied technological advances geared to utilization, development of bio-processes that depolymerize lignin and utilize the broad array of monomeric lignin breakdown products created during industrial pulping could create an array of feedstocks similar to those derived from petroleum sources. Adapting microbial systems to utilize raw lignin, while producing platform chemicals useful for polymer development, is an important step in this process [57].

\subsection{Brown Rot Fungi}

Brown rot fungi have received less study for biotechnological applications, primarily because their ability to rapidly depolymerize the carbohydrate fraction of the wood was viewed as having little practical application. However, more recent studies indicate that some CAZymes, such as lytic polysaccharide monooxygenases (LMPOs), have the ability to work synergistically with peroxidases to promote depolymerization and solubilization of aromatic monomers from lignin [37,58]. These results suggest that cellulase enzymes from either white or brown rot fungi could play a greater role in lignin depolymerization for use as a chemical feedstock. CAZymes from brown rot fungi have not been explored to a great extent largely because they are less common compared to white rot fungi. LPMO enzymes from brown rot fungi have only been isolated within the last five years, and have not been fully explored for use in industrial applications. Preliminary reports suggest that an LMPO from the brown rot fungus Gloeophyllum spp. cloned into yeast has significant potential for biorefinery applications $[37,59]$. Studies have tended to look for one or a few mechanisms of action, but it may be 
necessary to change the paradigm by combining enzymatic and non-enzymatic mechanisms under controlled conditions to either modify fibers or create platform chemicals [38].

The non-enzymatic activity of brown rot fungi has previously been shown to activate lignin for production of laminated wood [60] and composite panels [61]. Brown rotted lignin modified with a sodium borohydride treatment was previously used to produce a formaldehyde-free adhesive resin with properties close to that of phenolic resins [62]. The CMF mechanism from fungal systems has been used to activate lignin on fiber surfaces for the producing fiber-based products at an experimental level and has been shown to have potential industrial applications [63-66]. Lignin has also been modified using a CMF system to produce water-soluble polymers that have potential applications as a high-value dispersant comparable to poly(acrylic) acid [67].

Brown rot fungi have also been explored for bioremediation, especially for removal of copper and other heavy metals. Serpula spp. has been shown to remove copper from preservative-treated wood [68]. CMF chemistry also has effectively degraded pollutants like 2,4-dichlorophenol [69], dichloro-diphenyl-trichloroethane (DDT) [70] and pentachlorophenol [71] as well as decolorizing recalcitrant dyes [72,73]. An improved understanding of brown rot mechanisms over the past 20 years has encouraged a re-examination of using these fungi in bioremediation.

Brown rot fungi have also successfully been used to pretreat bagasse, wood and other lignocellulose substrates to promote cellulose and hemicellulose depolymerization for biorefinery applications [74]. The Mycologix LTD company [75] successfully pretreated biomass in a commercial application, but dramatic decreases in the cost of competing fossil hydrocarbons led the company to declare corporate insolvency. The initial success of this process suggests that similar efforts will emerge as the economies of the process improve and hydrocarbon prices rise. While the need for biofuels may be somewhat mitigated by the emergence of other renewable energy sources, liquid fuels will continue to be required in many industries. The use of brown rot systems for biomass preparation in biorefineries will likely increase, and markets for the lignin residues produced in these processes will be needed, creating opportunities for developing lignin-based coatings as well as polymeric resins.

\section{Relationship between Understanding Fungal Decay and Developing More Rational Wood Protection Methods}

Humans have long labored to limit the risk of decay and prolong the useful life of timber. Initially, they did so without even knowing that fungi were the causal agents, but emerging knowledge led to the development of a range of biocides that could protect timber from decay. Interestingly, many of these advances, such as the development of creosote preceded that understanding. As a result, wood protection largely remains a combination of effective designs that limit moisture, coupled with the use of naturally durable timbers or impregnation with biocides where moisture control is not possible. However, the types of biocides being used, and their method of application, is changing as concerns emerge about the use of all chemicals in the environment. These concerns have created opportunities to develop more rationale methods for protecting timber based upon our understanding of wood science and fungal physiology.

Current efforts to protect wood without biocides have focused methods such as thermal modification and chemical wood modification with techniques such as acetylation. Both techniques were explored in the middle of the 20th Century but were dropped at that time because they were not considered economical, but their use is now being resurrected. Thermal modification and acetylation function to limit water uptake by wood, but there may be more subtle approaches to wood protection under in some environments. For example, our improved understanding of the roles of free radicals in the degradation process has also been exploited experimentally through the use of anti-oxidants to protect wood [76]. The use of many plant-based extracts follows a similar path but uses a less specific approach since these treatments are often mixtures of compounds. While still not commercially used, they illustrate the potential for using our knowledge of microbial decomposition mechanisms to identify more rationale prevention strategies. 


\section{Coatings for Bio-Based Materials and the Need for Better Protection against Fungi}

While coatings have long been successfully used to impede and in some cases prevent fungal degradation while also limiting UV degradation, it is critical to understand both their function and limitations. The long-term effectiveness of any coating is dependent on its ability to prevent water penetration leading to coating failure and subsequent penetration by fungal hyphae or their enzymes and low-molecular weight metabolites through, around or behind the coating and into the wood. Coating efficacy is achieved via barrier technology and/or enhanced moisture exclusion. Loss of coating efficacy is often associated with increased moisture retention that can promote decay.

The general issues relating to coating failures for wood materials have been well summarized previously [77]. Decades of research at the U.S. Forest Products Laboratory showed that most paint coatings usually cracked at the wood joints or knots due to differential dimensional stability. Water enters the wood through these cracks and is trapped. Wood moisture content can then quickly reach the range suitable for fungal attack. Oil-based or alkyd-based paints contain oils that cure by reacting with oxygen to form cross-linked polymeric films. The more cross-linked the polymer, the more resistant it is to either liquid or vapor water. Latex paints form a film by coalescence of small spherical polymeric particles dispersed in water. These polymers are more flexible and not as highly cross-linked as cured oil-based paints, and generally remain more flexible with age. As a result, they provide less of a barrier to water ingress. Oil-based paint films generally provide superior initial water resistance; however, they become brittle over time.

As noted in the introduction to this chapter, moisture content changes with wood shrinkage and swelling are an issue which must be considered relative to the development of advanced coatings for wood products. Coatings must be designed to flex to accommodate changes in wood dimensions with wetting and drying. However, even under the best of circumstances, most coatings will fatigue and develop fine micro-fractures after thousands of shrinkage/swelling cycles. These fine micro-fractures are exploited by fungi that then penetrate into the wood beneath. This is particularly true in exterior environments where UV exposure weakens the coating thereby enhancing dimensional change stresses and promoting fractures (Figure 3). This can occur in seemingly impermeable barriers. For example, 1-2 mm thick polyurea coatings were penetrated by decay fungi over a four-year exposure in Hilo, Hawaii [78].
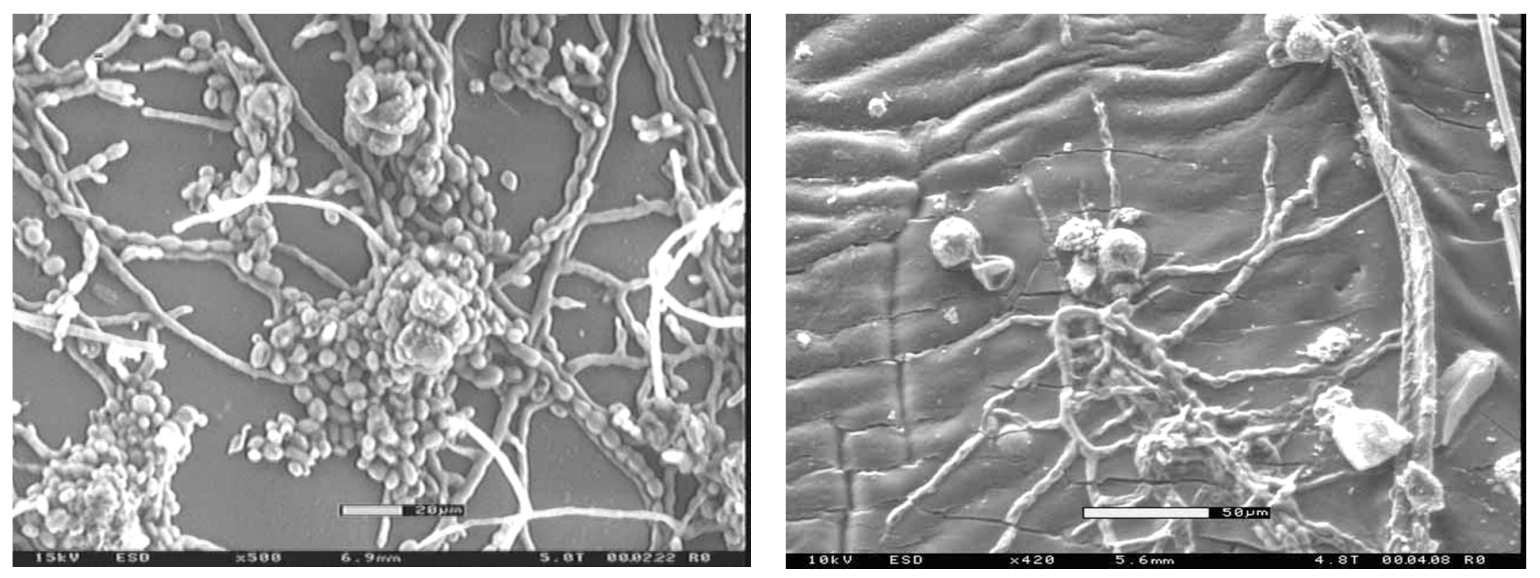

Figure 3. Scanning electron micrographs showing (a) fungal spores and hyphae growing on the surface of a new coating surface and (b) fungal spores and hyphae growing on an aged coating surface containing microcracks that can be exploited by fungal hyphae (Goodell images).

While we have previously discussed the decay process, hyphae of some decay and stain fungi also have the ability to directly penetrate wood cell walls using combinations of enzymatic/catalytic dissolution and mechanical/physical force. The mechanical forces generated by fungal hyphae can drive a fungal peg through a metal foil [79], even in the absence of enzymatic or catalytic action. This 
force is certainly great enough to allow fungi to penetrate many types and thicknesses of polymeric coatings, and the presence of surface micro-cracks undoubtedly aids in this process. Minimizing surface defects, slowing micro-crack development and even limiting hyphal growth on the coating surface (via the presence of biocides) can all contribute to limiting fungi compromising the coating barrier. A more difficult goal will be the development of clear coatings for exterior applications. Consumers generally prefer clear finishes so that they can see the wood; however, these coatings tend to be more susceptible to UV damage that leads to coating failures and, ultimately premature replacement of the timber $[10,80]$.

Coated surfaces are bombarded with fungal spores along with dust, pollen, plant sap and a host of other potential nutrient sources for a fungus. Many paint film fungi utilize these nutrients to begin growth (Figure 3) and eventually exploit coating defects to penetrate into the wood beneath (Figure 4). Once inside, they preferentially colonize the layer between the coating and the wood, leading to further coating failure (Figure 5). The extent of this problem in both clear and opaque coatings highlights the need for coating formulations that contain long-lasting fungal biocides or other protection systems that can prevent fungi from causing this type of failure. It may also be useful to explore self-cleaning systems [81]. For example, developing superhydrophobic surfaces that mimic natural phenomena such as the self-cleaning capacity of lotus leaves would reduce accumulation of surface debris that supports fungal growth.

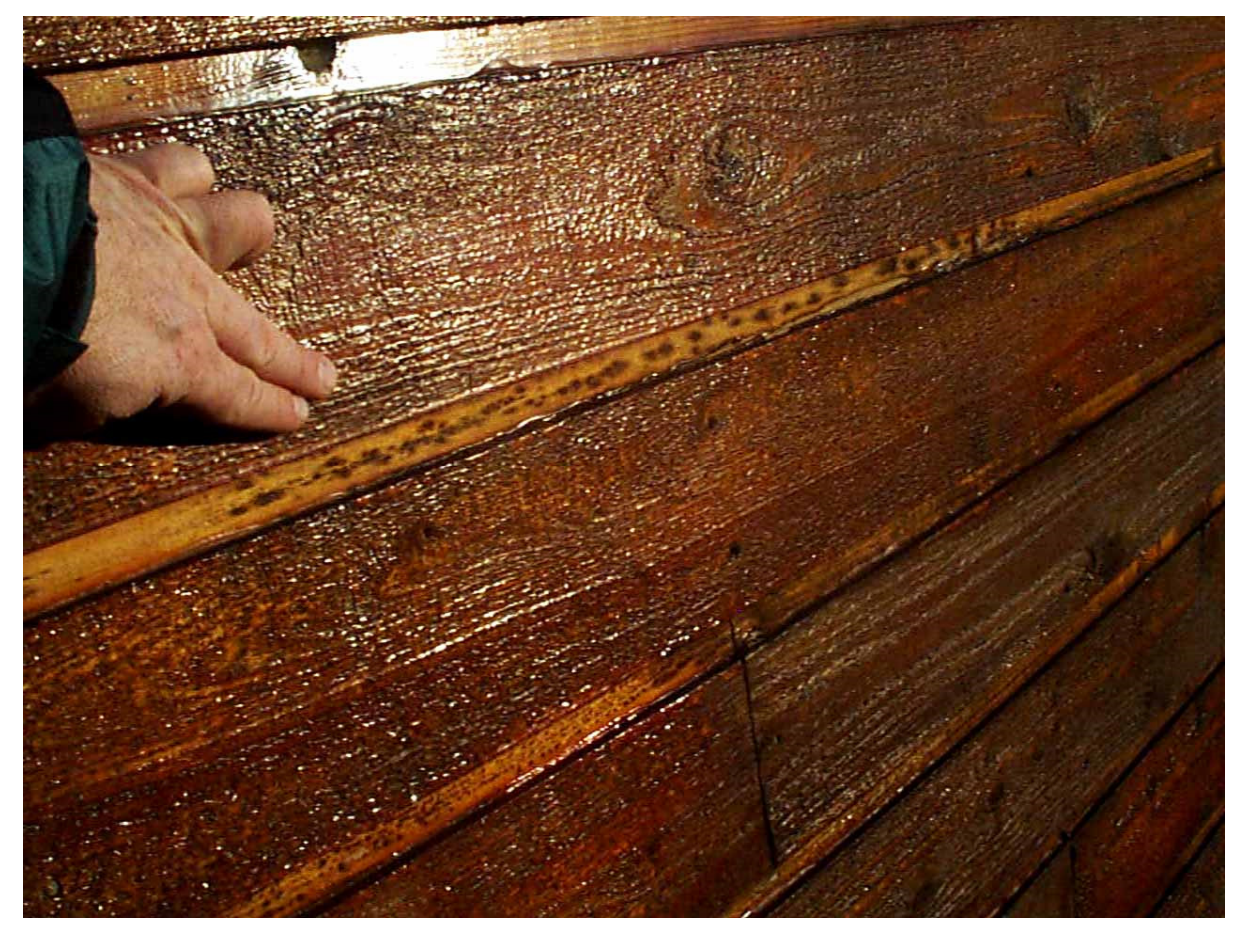

Figure 4. An example of fungal growth that has developed underneath a coating film (on the wood strip below hand) by penetrating the coating surface. This type of fungal attack occurs with opaque coatings as well, but it is readily observed when clear-polymer coatings are attacked. Clear coatings typically lack adequate UV resistance leading to development of micro-cracks in the coatings that fungi can exploit. (Goodell photo). 


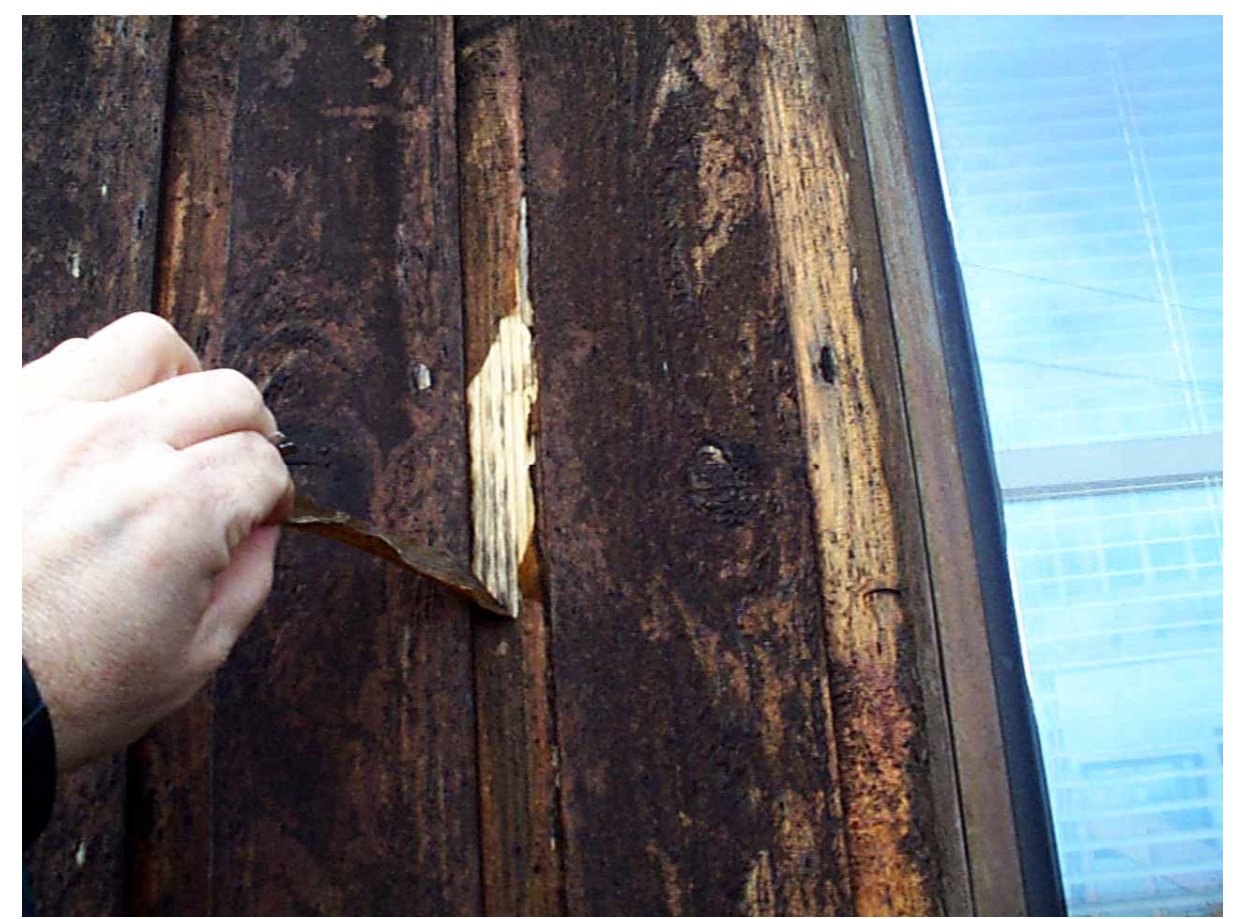

Figure 5. Example of a delaminated clear polymeric coating on wood being peeled from the surface after three years of exposure in a damp exterior environment. In this example, the finish was originally clear, similar to that seen in Figure 4. Fungi were involved in darkening of the finish and also, once they penetrated the coating film, in the delamination of the coating from the wood surface. In this example, the manufacturer's use of iron in the coating formulation also promoted the extreme darkening of the coating as, in this wet environment, wood extractives were driven to the surface, and these extractives reacted with the iron in the coating to produce the intense dark coloration (Goodell photo).

\section{Future Needs and Opportunities}

There is a critical need for an expanded understanding of how fungi attack and exploit current wood coatings to enable development of strategies to prevent premature damage to both the coating and the substrates they are intended to protect. Integrated technologies are needed to reduce fungal attack and enhance coating performance against physical and environmental factors. For example, enhanced UV protection coupled with better matching of long-term coating elasticity with expansion/contraction characteristics of the wood will limit the development of coating defects that fungi are known to exploit. Enhanced abrasion resistance and improved ability to shed environmental residues deposited on the coating will limit the ability of fungi to grow on and into the coating. Enhanced water repellency helps coatings shed water and reduces the time that a surface remains wet enough to permit fungal growth.

Biocides such as 3-iodo-2propynyl butyl carbamate and chlorothalonil have long been a component in many coating systems both for protecting the system against microbial attack prior to application as well as limiting fungal discoloration afterwards. While biocides ranging from tin and copper compounds to thiabendazoles are effective, they are not compatible with all polymeric systems. Novel approaches such as non-biocidal treatments that discourage attack by preventing fungal attachment to surfaces and preventing the development of biofilms have shown promise in the laboratory [82], but utilization of these coatings will likely remain limited to medical applications. While agricultural applications for this type of technology are proposed, it remains to be seen if cost-effective products can be developed that meet consumer needs for long-lasting surface protection under extreme UV exposures.

At present, a majority of coatings research remains proprietary, making it difficult to accurately assess the state of the science. However, market observations suggest that better coatings systems are still needed, and that fungal and UV resistance of coating systems has not dramatically improved in 
many consumer-available coatings in the past 20 years. The lack of long-lasting UV and moisture resistant coatings leads to premature replacement of functional structures, especially decking and this, in turn sharply reduces the normally positive life cycle attributes of timber. Developing a better understanding the mechanisms underlying fungal degradation of substrates, and the mechanisms involved in new biocidal and non-biocidal coating treatments will be essential for creating integrated coatings systems capable of limiting fungal attack while providing long term protection against environmental factors.

Funding: The first author was supported in part by the National Institute of Food and Agriculture, U.S. Department of Agriculture, the Center for Agriculture, Food and the Environment and the Microbiology department at University of Massachusetts Amherst, under project No. S1075-MAS00503. The contents are solely the responsibility of the authors and do not necessarily represent the official views of the USDA or NIFA.

Conflicts of Interest: The authors declare no conflict of interest with the content of this review.

\section{References}

1. Côté, W.A. Chemical Composition of Wood. In Principles of Wood Science and Technology; Solid Wood; Kollmann, F., Cote, W., Eds.; Springer: New York, NY, USA; Berlin/Heidelberg, Germany, 1968; Volume 1, pp. 55-78.

2. Mittal, N.; Ansari, F.; Gowda, V.K.; Brouzet, C.; Chen, P.; Larsson, P.T.; Söderberg, L.D. Multiscale Control of Nanocellulose Assembly: Transferring Remarkable Nanoscale Fibril Mechanics to Macroscale Fibers. Acs Nano 2018, 12, 6378-6388. [CrossRef] [PubMed]

3. Altgen, M.; Kyyrö, S.; Paajanen, O.; Rautkari, L. Resistance of thermally modified and pressurized hot water extracted Scots pine sapwood against decay by the brown-rot fungus Rhodonia placenta. Eur. J. Wood Wood Prod. 2020, 78, 161-171. [CrossRef]

4. Militz, H.; Altgen, M. Processes and properties of thermally modified wood manufactured in Europe. In Deterioration and Protection of Sustainable Biomaterials; Schultz, T.P., Goodell, B., Nicholas, D.D., Eds.; American Chemical Society: Washing, DC, USA, 2014; Volume 1158, pp. 269-286.

5. Winandy, J.E.; LeVan, S.L.; Ross, R.J.; Hoffman, S.P.; McIntyre, C.R. Thermal Degradation of Fire-Retardant-treated Plywood: Development and Evaluation of a Test Protocol; Research Paper FPL-RP-501; USDA, Forest Service: Madison, WI, USA, 1991.

6. Winandy, J.E. Relating wood chemistry and strength: Part II. Fundamental relationships between changes in wood chemistry and strength of wood. Wood Fiber Sci. 2017, 47, 2-11.

7. Winandy, J.E.; Morrell, J.J. Relationship between incipient decay, strength, and chemical composition of Douglas-fir heartwood. Wood Fiber Sci. 1993, 25.

8. Curling, S.; Clausen, C.A.; Winandy, J.E. Relationships between mechanical properties, weight loss, and chemical composition of wood during brown rot decay. For. Prod. J. 2002, 52, 34-39.

9. Kirker, G.; Winandy, J. Above Ground Deterioration of Wood and Wood-Based Materials. In Deterioration and Protection of Sustainable Biomaterials; American Chemical Society: Washington, DC, USA, 2014; Volume 1158, pp. 114-129.

10. Evans, P.D. Weathering and Photoprotection of Wood. In Development of Commercial Wood Preservatives; American Chemical Society: Washington, DC, USA, 2008; Volume 982, pp. 69-117.

11. Hon, D.N.S.; Feist, W.C. Weathering characteristics of hardwood surfaces. Wood Sci. Technol. 1986, 20, 169-183. [CrossRef]

12. Williams, R.S.; Winandy, J.E.; Feist, W.C. Adhesion of paint to weathered wood. For. Prod. J. 1987, 37, $29-31$.

13. Williams, R.S.; Lacher, S.; Winandy, J.E.; Halpin, C.; Feist, W.C.; White, C. Comparison of traditional methods for testing paint service life with new methods for service life prediction. In Proceedings of the 3rd International Symposium on Surfacing and Finishing of Wood, Kyoto, Japan, 24-26 November 2004; pp. 167-190, Sponsored by IUFRO Division 5.04.12.

14. Lebow, P.K.; Winandy, J.E. Verification of the kinetics-based model for long-term effects of fire retardants on bending strength at elevated temperatures. Wood Fiber Sci. 1999, 31, 49-61. 
15. LeVan, S.; Ross, R.J.; Winandy, J.E.; Laboratory, F.P. Effects of Fire Retardant Chemicals on the Bending Properties of Wood at Elevated Temperatures; U.S. Department of Agriculture, Forest Service, Forest Products Laboratory: Madison, WI, USA, 1990.

16. Sweet, M.S.; Winandy, J.E. Influence of Degree of Polymerization of Cellulose and Hemicellulose on Strength Loss in Fire-Retardant-Treated Southern Pine. Holzforschung 1964, 53, 311. [CrossRef]

17. Stamm, A.J. Wood and Cellulose Science; Ronald Press Co.: New York, NY, USA, 1964.

18. Cragg, S.M.; Beckham, G.T.; Bruce, N.C.; Bugg TD, H.; Distel, D.L.; Dupree, P.; Zimmer, M. Lignocellulose degradation mechanisms across the Tree of Life. Curr. Opin. Chem. Biol. 2015, 29, 108-119. [CrossRef]

19. Elam, J.; Björdal, C. A review and case studies of factors affecting the stability of wooden foundation piles in urban environments exposed to construction work. Int. Biodeterior. Biodegrad. 2020, 148, 104913. [CrossRef]

20. Zabel, R.A.; Morrell, J.J. Wood Microbiology: Decay and Its Prevention, 2nd ed.; Academic Press: San Diego, CA, USA, 2020; 556p, ISBN 978-0-12-819465-2.

21. Viitanen, H.; Toratti, T.; Makkonen, L.; Peuhkuri, R.; Ojanen, T.; Ruokolainen, L.; Räisänen, J. Towards modelling of decay risk of wooden materials. Eur. J. Wood Wood Prod. 2010, 68, 303-313. [CrossRef]

22. Jakes, J.E.; Zelinka, S.L.; Hunt, C.G.; Ciesielski, P.; Frihart, C.R.; Yelle, D.; Vogt, S. Measurement of moisture-dependent ion diffusion constants in wood cell wall layers using time-lapse micro X-ray fluorescence microscopy. Sci. Rep. 2020, 10, 9919. [CrossRef] [PubMed]

23. Miller, D.J.; Goodell, B. Blue staining in ponderosa pine sapwood at moderate and low temperatures. For. Prod. J. 1981, 31, 54-59.

24. Smith, R.S.; Ofosu-Asiedu, A. Distribution of thermophilic and thermotolerant fungi in a spruce-pine chip pile. Can. J. For. Res. 1972, 2, 16-26. [CrossRef]

25. Horvath, Z.; Marosvölgyi, B.; Idler, C.; Pecenka, R.; Lenz, H. Storage problems of poplar chips from short rotation plantations with special emphasis on fungal development. Acta Silv. Lignaria Hung. 2012, 8, 123-132. [CrossRef]

26. Wilcox, W.W. Review of literature on the effects of early stages of decay on wood strength. Wood Fiber 1978, 9, 252-257.

27. Gerke, J.; Köhler, A.M.; Meister, C.; Thieme, K.G.; Amoedo, H.; Braus, G.H. Coordination of fungal secondary metabolism and development. In Genetics and Biotechnology. The Mycota (a Comprehensive Treatise on Fungi as Experimental Systems for Basic and Applied Research), vol. 2; Benz, J.P., Schipper, K., Eds.; Springer: Cham, Switzerland; New York, NY, USA, 2020. [CrossRef]

28. Lücking, R.; Huhndorf, S.; Pfister, D.H.; Plata, E.R.; Lumbsch, H.T. Fungi evolved right on track. Mycology 2009, 101, 810-822. [CrossRef]

29. Prieto, M.; Wedin, M. Dating the Diversification of the Major Lineages of Ascomycota (Fungi). PLoS ONE 2013, 8, e65576. [CrossRef]

30. Bhatt, M.; Mistri, P.; Joshi, I.; Ram, H.; Raval, R.; Thoota, S.; Joshi, M. Molecular survey of basidiomycetes and divergence time estimation: An Indian perspective. PLoS ONE 2018, 13, e0197306. [CrossRef]

31. Floudas, D.; Binder, M.; Riley, R.; Barry, K.; Blanchette, R.A.; Henrissat, B.; Martínez, A.T.; Ortillar, R.; Spatafora, J.W.; Yadav, J.S.; et al. The paleozoic origin of white rot wood decay reconstructed using 31 fungal genomes. Science 2012, 336, 1715-1719. [CrossRef] [PubMed]

32. Eastwood, D.C. The evolution of fungal wood decay. In Deterioration and Protection of Sustainable Biomaterials; Nicholas, D.D., Goodell, B., Schultz, T.P., Eds.; American Chemical Society; Oxford University Press: Washington, DC, USA, 2014; Volume 1158, pp. 93-112.

33. Nelsen, M.P.; DiMichele, W.A.; Peters, S.E.; Boyce, C.K. Delayed fungal evolution did not cause the paleozoic peak in coal production. Proc. Natl. Acad. Sci. USA 2016, 113, 2442-2447. [CrossRef] [PubMed]

34. R Riley, R.; Salamov, A.A.; Brown, D.W.; Nagy, L.G.; Floudas, D.; Held, B.W.; Grigoriev, I.V. Extensive sampling of basidiomycete genomes demonstrates inadequacy of the white-rot/brown-rot paradigm for wood decay fungi. Proc. Natl. Acad. Sci. USA 2014, 111, 9923-9928. [CrossRef] [PubMed]

35. Krah, F.-S.; Bässler, C.; Heibl, C.; Soghigian, J.; Schaefer, H.; Hibbett, D.S. Evolutionary dynamics of host specialization in wood-decay fungi. BMC Evol. Biol. 2018, 18, 119. [CrossRef] [PubMed]

36. Curling, S.; Clausen, C.A.; Winandy, J.E. The Effect of Hemicellulose Degradation on the Mechanical Properties of Wood during Brown Rot Decay; International Research Group on Wood Preservation (IRG), Document No IRG/WP/01-20219; IRG: Stockholm, Sweden, 2001; pp. 1-10. 
37. Zhu, Y.; Plaza, N.; Kojima, Y.; Yoshiida, M.; Zhang, J.; Jellison, J.; Pingali, S.V.; O’Neill, H.; Goodell, B. Nanostructural analysis of enzymatic and non-enzymatic brown-rot fungal deconstruction of the lignocellulose cell wall. Front. Microbiol. 2020, 11. [CrossRef]

38. Goodell, B.; Zhu, Y.; Kim, S.; Kafle, K.; Eastwood, D.; Daniel, G.; O’Neill, H. Modification of the nanostructure of lignocellulose cell walls via a non-enzymatic lignocellulose deconstruction system in brown rot wood-decay fungi. Biotechnol. Biofuels 2017, 10, 179. [CrossRef]

39. Goodell, B. Fungi involved in the biodeterioration and bioconversion of lignocellulose substrates. (chapter 15). In The Mycota. Genetics and Biotechnology, (a Comprehensive Treatise on Fungi as Experimental Systems for Basic and Applied Research), 3rd ed.; Benz, J.P., Schipper, k., Eds.; Springer: Cham, Switzerland, 2020; Volume II, pp. 369-397. [CrossRef]

40. Savory, J.G. Damage to wood caused by microorganisms J. Appl. Bacteriol. 1954, 17, 213-218. [CrossRef]

41. Daniel, G.; Nilsson, T. Chapter 3. Development in the study of soft rot and bacterial decay. In Forest Products Biotechnology; Bruce, A., Palfreyman, J., Eds.; Taylor and Francis Publishers: London, UK, 1998; pp. 235-250.

42. Blanchette, R.A.; Burnes, T.A.; Leatham, G.F.; Effland, M.J. Selection of white-rot fungi for biopulping. Biomass 1988, 15, 93-101. [CrossRef]

43. Wolfaardt, F.; Taljaard, J.L.; Jacobs, A.; Male, J.R.; Rabie, C.J. Assessment of wood-inhabiting Basidiomycetes for biokraft pulping of softwood chips. Bioresour. Technol. 2004, 95, 25-30. [CrossRef]

44. Eriksson, K.E.L. Biopulping, biobleaching and treatment of kraft bleaching effluents with white-rot fungi. In Comprehensive Biotechnology; Moo, Y., Ed.; Pergamon Press: Toronto, ON, USA, 1985; Volume 4, pp. 271-294.

45. Widsten, P.; Kandelbauer, A. Adhesion improvement of lignocellulosic products by enzymatic pre-treatment. Biotechnol. Adv. 2008, 26, 379-386. [CrossRef]

46. Kharazipour, A.; Bergmann, K.; Nonninger, K.; Huttermann, A. Properties of fibre boards obtained by activation of the middle lamella lignin of wood fibres with peroxidase and $\mathrm{H} 2 \mathrm{O} 2$ before conventional pressing. J. Adhes. Sci. Technol. 1998, 12, 1045-1053. [CrossRef]

47. Malinowski, S.; Herbert, P.A.F.; Rogalski, J.; Jaroszyńska-Wolińska, J. Laccase enzyme polymerization by soft plasma jet for durable bioactive coatings. Polymers 2018, 10, 532. [CrossRef] [PubMed]

48. Barr, D.P.; Aust, S.D. Mechanisms white rot fungi use to degrade pollutants. Environ. Sci. Technol. 1994, 28, 79A-87A. [CrossRef] [PubMed]

49. Magan, N.; Fragoeiro, S.; Bastos, C. Environmental factors and bioremediation of xenobiotics using white rot fungi. Mycobiology 2010, 38, 238-248. [CrossRef] [PubMed]

50. Dashtban, M.; Schraft, H.; Syed, T.A.; Qin, W. Fungal biodegradation and enzymatic modification of lignin. Int. J. Biochem. Mol. Biol. 2010, 1, 36-50.

51. Baba, Y.; Tanabe, T.; Shirai, N.; Watanabe, T.; Honda, Y.; Watanabe, T. Pretreatment of Japanese cedar wood by white rot fungi and ethanolysis for bioethanol production. Biomass Bioenergy 2011, 35, 320-324. [CrossRef]

52. Capolupo, L.; Faraco, V. Green methods of lignocellulose pretreatment for biorefinery development. Appl. Microbiol. Biotechnol. 2016, 100, 9451-9467. [CrossRef]

53. Singh, D.; Chen, S. The white-rot fungus Phanerochaete chrysosporium: Conditions for the production of lignin-degrading enzymes. Appl. Microbiol. Biotechnol. 2008, 81, 399-417. [CrossRef]

54. López, A.M.Q.; Silva, A.L.d.S.; Santos, E.C.L.d. The fungal ability for biobleaching/biopulping/bioremediation of lignin-like compounds of agro-industrial raw material. Química Nova 2017, 40, 916-931. [CrossRef]

55. Bissaro, B.; Várnai, A.; Røhr, Å.K.; Eijsink, V.G.H. Oxidoreductases and Reactive Oxygen Species in Conversion of Lignocellulosic Biomass. Microbiol. Mol. Biol. Rev. 2018, 82, e00029-18. [CrossRef]

56. Hwan Kim, Y.; Suk An, E.; Keun Song, B.; Shik Kim, D.; Chelikani, R. Polymerization of cardanol using soybean peroxidase and its potential application as anti-biofilm coating material. Biotechnol. Lett. 2003, 25, 1521-1524. [CrossRef] [PubMed]

57. Qian, Y.; Otsuka, Y.; Sonoki, T.; Mukhopadhyay, B.; Nakamura, M.; Jellison, J.; Goodell, B. Engineered Microbial Production of 2-Pyrone-4,6-Dicarboxylic Acid from Lignin Residues for Use as an Industrial Platform Chemical. BioResources 2016, 11, 6097-6109. [CrossRef]

58. Li, F.; Ma, F.; Zhao, H.; Zhang, S.; Wang, L.; Zhang, X.; Yu, H. A lytic polysaccharide monooxygenase from a white-rot fungus drives the degradation of lignin by a versatile peroxidase. Appl. Environ. Microbiol. 2019, 85, e02803-e02818. [CrossRef] [PubMed] 
59. Kojima, Y.; Varnai, A.; Ishida, T.; Sunagawa, N.; Petrovic, D.M.; Igarashi, K.; Jellison, J.; Goodell, B.; Alfredsen, G.; Westereng, B.; et al. A lytic polysaccharide monooxygenase with broad xyloglucan specificity from the brown-rot fungus gloeophyllum trabeum and its action on cellulose-xyloglucan complexes. Appl. Environ. Microbiol. 2016, 82, 6557-6572. [CrossRef] [PubMed]

60. Jin, L.; Nicholas, D.D.; Schultz, T.P. Wood laminates glued by enzymatic oxidation of brown-rotted lignin. Holzforschung 1991, 45, 467-468.

61. Jin, L.; Sellers, T., Jr.; Schultz, T.P.; Nicholas, D.D. Utilization of Lignin Modified by Brown-Rot Fungi. I. Properties of Flakeboard Produced with a Brown-rotted Lignin Modified Phenolic Adhesive. Holzforschung 1990, 44, 207-210. [CrossRef]

62. Li, K.; Geng, X. Formaldehyde-Free Wood Adhesives from Decayed Wood. Macromol. Rapid Commun. 2005, 26, 529-532. [CrossRef]

63. Qian, Y.; Goodell, B.; Genco, J.M. The effect of a chelator mediated fenton system on the fiber and paper properties of hardwood kraft pulp. J. Wood Chem. Technol. 2002, 22, 267-284. [CrossRef]

64. Qian, Y.; Goodell, B.; Jellison, J.; Felix, C.C. The Effect of Hydroxyl Radical Generation on Free-Radical Activation of TMP Fibers. J. Polym. Environ. 2004, 12, 147-155. [CrossRef]

65. Goodell, B.; Jellison, J. Oxidation Using a Non-Enzymatic Free Radical System Mediated by Redox Cycling Chelators. U.S. Patent No. 7396974B2. Available online: https://patents.google.com/patent/US7396974B2/en: USPTO (accessed on 13 September 2019).

66. Yelle, D.; Goodell, B.; Gardner, D.; Amirbahman, A.; Winistofer, P.; Shaler, S. Bonding of wood fiber composites using a synthetic chelator-lignin activation system. For. Prod. J. 2004, 54, 73-78.

67. Kent, M.S.; Zeng, J.; Rader, N.; Avina, I.C.; Simoes, C.T.; Brenden, C.K.; Sale, K.L. Efficient conversion of lignin into a water-soluble polymer by a chelator-mediated Fenton reaction: Optimization of $\mathrm{H}_{2} \mathrm{O}_{2}$ use and performance as a dispersant. Green Chem. 2018, 20, 3024-3037. [CrossRef]

68. Kartal, S.N.; Terzi, E.; Yilmaz, H.; Goodell, B. Bioremediation and decay of wood treated with ACQ, micronized ACQ, nano-CuO and CCA wood preservatives. Int. Biodeterior. Biodegrad. 2015, 99, 95-101. [CrossRef]

69. Ren, H.; Jin, X.; Li, C.; Li, T.; Liu, Y.; Zhou, R. Rosmarinic acid enhanced Fe(III)-mediated Fenton oxidation removal of organic pollutants at near neutral pH. Sci. Total Environ. 2020, 736, 139528. [CrossRef] [PubMed]

70. Purnomo, A.S.; Kamei, I.; Kondo, R. Degradation of 1,1,1-trichloro-2,2-bis (4-chlorophenyl) ethane (DDT) by brown-rot fungi. J. Biosci. Bioeng. 2008, 105, 614-621. [CrossRef] [PubMed]

71. Goodell, B.; Jellison, J.; Liu, J.; Daniel, G.; Paszczynski, A.; Fekete, F.; Xu, G. Low Molecular Weight Chelators And Phenolic Compounds Isolated from Wood Decay Fungi and their Role in the Fungal Biodegradation of Wood. J. Biotechnol. 1997, 53, 133-162. [CrossRef]

72. Goodell, B.; Qian, Y.; Jellison, J.; Richard, M.; Qi, W. Lignocellulose oxidation by low molecular weight metal-binding compounds isolated from wood degrading fungi: A comparison of brown rot and white rot systems and the potential application of chelator-mediated fenton reactions. In Progress in Biotechnology 21. Biotechnology in the Pulp and Paper Industry; Lantto, L.V.a.R., Ed.; Elsevier Press: Amsterdam, The Netherlands, 2002; pp. 37-49.

73. Goodell, B.; Qian, Y.; Jellison, J.; Richard, M. Decolorization and degradation of dyes with mediated Fenton reaction. Water Environ. Res. 2004, 76, 2703-2707. [CrossRef]

74. Ray, M.J.; Leak, D.J.; Spanu, P.D.; Murphy, R.J. Brown rot fungal early stage decay mechanism as a biological pretreatment for softwood biomass in biofuel production. Biomass Bioenergy 2010, 34, 1257-1262. [CrossRef]

75. CompaniesHouse.Gov.UK; Mycologix Ltd. CompaniesHouse.Gov.UK. 2013. Available online: https: //beta.companieshouse.gov.uk/company/07002759 (accessed on 13 September 2019).

76. Schultz, T.P.; Nicholas, D.D. Improving the Performance of Organic Biocides by Using Economical and Benign Additives. In Development of Commercial Wood Preservatives; American Chemical Society: Washington, DC, USA, 2008; Volume 982, pp. 272-284.

77. Williams, R.S.; Knaebe, M.T.; Feist, W.C. Finishes for Exterior Wood: Selection, Application E Maintenance; USDA. Forest Products Society: Madison, WI, USA, 1996; p. 127.

78. Konkler, M.J.; Cappellazzi, J.; Morrell, J.J. Performance of polyurea-coated Douglas-fir timbers exposed in Hilo Hawaii. Int. Wood Prod. J. 2019, 10, 31-36. [CrossRef]

79. Liese, W. Ultrastructural Aspects of Woody Tissue Disintegration. Annu. Rev. Phytopathol. 1970, 8, 231-245. [CrossRef] 
80. Evans, P.D.; Thay, P.D.; Schmalzl, K.J. Degradation of wood surfaces during natural weathering. Effects on lignin and cellulose and on the adhesion of acrylic latex primers. Wood Sci. Technol. 1996, 30, 411-422. [CrossRef]

81. Yao, Y.; Gellerich, A.; Zauner, M.; Wang, X.; Zhang, K. Differential anti-fungal effects from hydrophobic and superhydrophobic wood based on cellulose and glycerol stearoyl esters. Cellulose 2018, 25, 1329-1338. [CrossRef]

82. Vallieres, C.; Hook, A.L.; He, Y.; Crucitti, V.C.; Figueredo, G.; Davies, C.R.; Avery, S.V. Discovery of (meth)acrylate polymers that resist colonization by fungi associated with pathogenesis and biodeterioration. Sci. Adv. 2020, 6, eaba6574. [CrossRef] [PubMed]

Publisher's Note: MDPI stays neutral with regard to jurisdictional claims in published maps and institutional affiliations.

(C) 2020 by the authors. Licensee MDPI, Basel, Switzerland. This article is an open access article distributed under the terms and conditions of the Creative Commons Attribution (CC BY) license (http://creativecommons.org/licenses/by/4.0/). 